\title{
Federal Relations Policy of A.C.R.L.
}

Dr. Wilson is chairman, A.C.R.L. Policy Committee, and director of libraries, University of Colorado.

$\mathrm{T}$ HE Board of Directors of A.C.R.L., meeting in Cleveland on July 2 I, I950, agreed to request the Policy Committee to draft a statement of long range policy in the area of federal relations. This assignment was accepted by the Policy Committee.

After studying various matters in this area which were of special interest to A.C.R.L. membership, and considering the machinery already in existence and assigned to consider such matters, the committee submitted a report which was accepted and approved by the board at its meeting in Chicago on January 3I. The major recommendation of the report is that "the general long term policy of A.C.R.L. in the area of federal relations shall be to cooperate with and operate through appropriate A.L.A. boards and committees." In making this recommendation the committee pointed out that "no interests of major significance in this area can be considered as being exclusively A.C.R.L. interests. This is an area in which the second cardinal policy of A.C.R.L., 'to make present affiliation with A.L.A. a fruitful relationship,' can be made particularly effective."

Implementation of this policy to assure the most effective results possible is not solely the responsibility of the Board of Directors and the executive secretary. Each member of A.C.R.L. must recognize, accept and be alert to his responsibilities in calling to the attention of A.C.R.L. officers any matters in the general area of federal rela- tions which should receive attention from and action by appropriate committees.

Examples in this area of some of the matters of special but not exclusive interest to A.C.R.L. members are :

I. The character of government publications, distribution of government documents, the library's use of government publications.

2. Research programs in the federal field which may involve dependence upon college, university and research libraries with the related questions of regional libraries, federal aid and cooperative arrangements with such federal libraries as the Library of Congress, the Army Medical Library and the U.S.D.A. Library.

3. Measures for the protection of the holdings of research libraries.

4. Liaison with federal agencies engaged in war mobilization activities.

5. The National Science Foundation Act, approved May IO, I950 (8Ist Congress, Public Law 507).

6. The National Clearing House for Scientific and Technical Information Act, approved Sept. 9, I950 (8I Ist Congress, Public Law 776).

7. Relations with the U.S. Office of Education.

8. Postal and customs legislation.

9. Social security.

Io. The Point Four Program.

I I. The world agreement to abolish duty on publications as approved at the Fifth General Conference of Unesco in MayJune I950.

12. Support of the Library of Congress in developing its services which have par- 
ticular significance to libraries throughout the nation.

Most of these are not new fields of interest, but the present state of our foreign relations makes numbers 2,3 and 4 assume immediate importance. Numbers 5 and 6 are important new federal laws which may be of great significance to research libraries in the years ahead. A review of functions of existing A.L.A. committees indicates that each of the preceding 12 matters of interest can be considered as lying within the areas established for the committees.

The function of the A.L.A. Federal Relations Committee is "to consider all matters involving federal legislative or governmental action affecting libraries not specifically assigned to other boards and committees, to watch federal legislation for matters which affect libraries, to further legislation in Congress, to protest any undesirable legislation proposed, to seek rulings and interpretations of laws and regulations, and to represent the A.L.A. before the federal government when necessary." 1

Examples of "other boards and committees" of A.L.A. which have been assigned to consider matters involving federal relations are:

I. Public Documents. "To take cognizance of matters relating to public documents issued in the United States, whether federal, state, or local, and matters relating to the official publications of foreign governments."

2. Book Acquisitions. "...to represent the association in negotiations with the book trade, and before legislative bodies in controversies relating to price maintenance, terms, copyrights, and kindred questions. ..."

3. Statistics. "To consider uniform an-

1 This and following statements of function of committees and boards are taken from "A.L.A. Organization and Information 1950-51." A.L.A. Bulletin 44:394431 , November 1950 . nual report forms and submit recommendations thereon; to coordinate statistical activities of the association and its affiliated agencies; to cooperate in statistical matters with the U.S. Office of Education. ..."

4. Resources of American Libraries. "To study the present resources of American libraries; to suggest plans for coordination in the acquisition of research publications by American libraries."

5. Public Relations. "To encourage and stimulate a sound public relations program for all types of libraries...."

6. International Relations. "... to have direct supervision of the association's international activities involving library cooperation. ...."

7. Government Publications. "To consider problems of publishing research reports and of storing materials for distribution after the war, of acquiring public documents and expediting their acquisition, and related matters." 2

In the area of government publications, a majority of the members of the A.L.A. Committee on Public Documents are staff members of college, university or research libraries, and two of the three listed members of the Joint Committee on Government Publications are university librarians. At the open meeting arranged by the A.L.A. Committee in Cleveland on July 18 , a symposium on federal depository libraries was presented, and three of the four participants were members of university library staffs. The January I95 I issue of College and Research Libraries published the four papers given at the symposium and two additional articles dealing with documents. The 25 pages devoted to these papers represented over one-fourth of the total space in the issue. These facts seem to indicate no need of a special A.C.R.L. committee to

\footnotetext{
2 This is a joint committee of A.L.A., American Association of Law Libraries, Association of Research Libraries, Special Libraries Association.
} 
look after the association's interest in this area.

The A.L.A. Board on Resources of American Libraries at present is composed of five university librarians, all of whom are active A.C.R.L. members, and the chairman is a past president of A.C.R.L. Four of the five members of the board also are from libraries which are members of the Association of Research Libraries. When A.R.L. at its February I meeting gave consideration to steps involved in mobilization of resources of research libraries to meet national needs in the present crisis, this overlapping membership was pointed out. The executive secretary of A.R.L. was instructed to confer with the chairman of the board, since the need for a special A.R.L. committee in this area was questioned. It would appear that interests of A.C.R.L. and A.R.L. members would not be slighted as the A.L.A. Board on Resources assumes leadership in this mobilization effort.

These two examples are cited to indicate specifically how existing A.L.A. boards and committees operate in this general area of federal relations. They should assure adequate coverage of all library interests where federal relations are involved. Every member of A.C.R.L. is also a member of A.L.A. and as such is interested in furthering all library interests. There are special interests of A.C.R.L. members, however, and these must not be neglected. College, university and reference librarians constitute a fairly large proportion of the membership of
A.L.A. committees.

If A.C.R.L. special interests are not receiving adequate attention from these A.L.A. committees it is the responsibility of A.C.R.L. officers and Board of Directors to call such neglect to the attention of the particular committees. If such neglect continues, A.C.R.L. has the right to request A.L.A. Council review of such committee actions-or inactions-and if satisfactory results are not then obtained, A.C.R.L. would be justified in establishing its own boards or committees to work independently. It is extremely doubtful that such a situation will occur.

The college, university and reference librarians serving on these A.L.A. boards and committees have a primary responsibility to keep in mind any special interests of A.C.R.L. members. Every A.C.R.L. member has the responsibility of bringing these interests to the attention of the appropriate A.L.A. committee, either directly as a member of A.L.A., or indirectly through A.C.R.L. officers, directors or section officers. The executive secretary of A.C.R.L. has a special responsibility to be alert to these interests and to suggest action programs. If each member and each officer of A.C.R.L. is alert to our needs and interests in the area of federal relations, the policy of cooperating with and operating through present organizational machinery of the A.L.A. should assure that these needs and interests will be met adequately and satisfactorily. 